UDC 613.6: 616.9-022.39-057 (571.13)

DOI: $10.21668 /$ health.risk/2017.2.11.eng

\title{
BIOLOGICAL, EPIDEMIOLOGICAL, SANITARY-HYGIENIC, MEDICAL AND BEHAVIORAL OCCUPATIONAL HEALTH RISK FACTORS FOR STOCK-BREEDERS, VETERINARIES AND WORKERS EMPLOYED AT MEAT-PROCESSING ENTERPRISES, CONTACTING BRUCELLAR ANIMALS AND INFECTED MEAT
}

\author{
S.I. Ereniev', O.V. Plotnikova', V.G. Demchenko ${ }^{1}$, N.V. Rudakov ${ }^{1,2}$ \\ ${ }^{1}$ Omsk State Medical University, 12 Lenina Str., Omsk, 644099, Russian Federation \\ ${ }^{2}$ Omsk Scientific Research Feral Herd Infections Institute, 7 Mira Str., Omsk, 644080, Russian Federation
}

\begin{abstract}
We have studied sanitary-hygienic characteristics of working conditions, charts with results of sanitaryepidemiologic examination performed in a zoogenous nidus, outpatient clinic cards and questionnaires filled in by 202 patients living in Omsk region and suffering from occupational brucellosis. The disease usually prevails among stock-breeders, veterinaries and workers employed at meat-processing enterprises. Our goal was to detect risks of occupational, production-induced and general pathology evolvement. Working conditions which all the examined people had to work in corresponded to hazardous (3.3) or even dangerous (4) category as per occurrence of contacts with infectious agents and parasites (biological risk). Apart from biological factor, a number of workers were under complex exposure to ammonia concentrations (higher than MPC), noise higher than MPL, vibration, cooling microclimate, uncomfortable lighting environment, labor process hardness and intensity. There were several factors causing epidemiologic risks as well. Disinfectants were absent or their quantity was

not sufficient; industrial and amenity rooms were not well-organized; there was no central hot water supply or shower rooms, separate rooms for meals, specialized implements for removing abortus and stillborn fetuses and afterbirths, correctly organized burial grounds, or first aid kits. Hygienic health risks were caused by insufficient cleaning agents supply, absence of centralized protecting clothing laundering, and insufficient provision with personal protection means. Occupational health risks resulted from absence of preliminary medical examinations in standard recruitment procedures, irregularity and low quality of periodical medical examinations. Our qualitative assessment of behavioral health risks revealed that a lot of workers tended to have irresponsible medical and hygienic behavior, there were disorders in their work and rest regime (shift work with shifts rotation), nutrition, sleeping and waking. We also found out that the examined workers didn't pursue self-preserving lifestyle as they drank alcohol, smoked, underestimated the importance of being vaccinated against brucellosis and of having medical examinations, and didn't apply for medical aid in due time. We detected the third type of risk-genous behavior, "high risk-genous level, passive" in $28.22 \%$ of our respondents.

Key words: brucellosis, workers employed in stock-breeding and at meat-processing enterprises, occupational risks, biological risks, epidemiological risks, sanitary-hygienic risksu, medical-preventive risks, behavioral risks.
\end{abstract}

There have been positive changes in oc- recently; they are determined by worldwide cupational hygiene and occupational pathology trend of a worker's health growing importance

(C) Ereniev S.I., Plotnikova O.V., Demchenko V.G., Rudakov N.V., 2017

Stepan I. Ereniev - Doctor of Medical Sciences, Professor at Occupational Hygiene and Occupational Pathology Department (e-mail: stepan_ereniev@ mail.ru; tel.: +7-913-635-13-66).

Olga V. Plotnikova - Candidate of Medical Sciences, Associate Professor, Head of Occupational Hygiene and Occupational Pathology Department (e-mail: olga.plotnikova7@ mail.ru; tel.: +7-913-974-31-36).

Vladimir G. Demchenko - Doctor of Medical Sciences, Professor at Occupational Hygiene and Occupational Pathology Department (e-mail: zefir46@ mail.ru; tel.: +7-906-990-92-29).

Nikolai V. Rudakov - Doctor of Medical Sciences, Professor, Head of Microbiology, Virology and Immunology Department (e-mail: rickettsia@ mail.ru; tel.: +7-903-981-13-58). 
as it underlies his or her labor efficiency and safety. And now we can see a necessity to change a paradigm: from a worker's safety and health to his or her health and safety. Within such an approach a working place is a place of high hygienic quality which is under an employer's constant control and where such working conditions are created that a worker can function decently without any occupational risks for his or her health. Federal state sanitary-epidemiologic surveillance in the sphere of providing biological and chemical safety becomes of great importance here [3,5].

Occupational zooanthroponoses include 23 nosologic groups and forms related to infectious, parasitic and protozoan diseases; brucellosis holds the first place among them [15], as its share among occupational infectious diseases has been equal to about $40 \%$ over the last few years.

The basic reasons causing occupational brucellosis are:

- occupational contact with an infectious factor when veterinary and sanitary rules are not observed;

- working places poorly arranged;

- absence of personal protection means [1].

Social and economic significance of brucellosis is determined by:

- the fact that the main affected group is working population;

-explicit trend of the disease becoming a chronic one (in 40-60\% of cases);

- possible eventual disability of patients (specific weight of disability amounts to one third of all the detected cases);

- necessity to bear substantial economic costs for examining population in order to detect primary contagion, and for treating brucellosis and its consequences;

- occupational nature of brucellosis.

In spite of relatively low level of registered brucellosis morbidity in the RF over the last 1015 years (0.3-0.4, not higher than 0.5 per 100 thousand people), the true parameters are much higher. Only first diagnosed ("fresh") cases are registered while chronic forms are not accounted. Approximately 5\% acute forms and $95 \%$ chronic forms of all the first diagnosed cases of occupational brucellosis are registered in Russia and it proves that the infection is detected too late. So we can state there are no data on true prevalence of brucellosis among the RF population.

Incomplete morbidity data are related not only to lower medical aid appealability among rural population, and decreases in volumes of scheduled prophylactic medical examinations of people employed in stockbreeding (including cattle owners), but also to underdeveloped laboratory diagnostics of brucellosis, especially its chronic forms $[16,17,18]$. But if a diagnosis is put promptly and correctly, and treatment is also prompt and starts in due time it leads to substantial decrease in infectious processes becoming chronic and in patients' disability [20].

More active "adjusting" appeal of people suffering from brucellosis to get a consultation from an occupational pathologist is one of the factors which underlie growth in occupational brucellosis detection; people appeal for medical aid to get confirmation that their disease is associated with their occupation [11].

An issue of brucellosis over the last years has been greatly determined by existing risks of carrying the infection with contaminated cattle coming from adverse territories of the neighboring states (Mongolia, Kazakhstan, Kirgizia and others) with the consequent formation of local infection niduses and possibility of unapparent brucellosis caused by Brucella abortus $[10,13]$.

Population migration which has grown over the last 2 decades and insufficient veterinary and sanitary control over imports of cattle from countries with adverse brucellosis situation, including neighboring CIS countries, can nowadays make poor epizootic and epidemiologic situation as per this infection even worse. Due to uncontrolled imports of cattle from adverse countries there have been cases of the infection carrying into Samara, Vladimir, Chelyabinsk, Sverdlovsk, Omsk, Kaluga, Murmansk, and Altai regions.

Rates of big and small cattle hygienics have decreased substantially over the last 2 decades. Trade in vaccinated animals' meat is 
prohibited in the WTO member countries; and in order to join the WTO, Kazakhstan eliminated annual two-time vaccination as vaccination with strain- 82 which had been adopted in the country earlier was considered by the WTO experts to be dangerous and causing the disease. As a result of this decision, mass epidemics among cattle occurred in Kazakhstan, and annually 2,500-3,500 new brucellosis cases are registered among people [4].

$17.1 \%$ of all brucellosis morbidity in the $\mathrm{RF}$ are detected in Siberian Federal District. Infected people are detected practically in all regions there. Adverse situation with small cattle brucellosis in Kazakhstan which borders Omsk region causes a threat of epidemiologic situation becoming worse. 167 brucellosis cases have been detected in Omsk region over the last 5 years; $28(16.77 \%)$ of them were occupational ones. In order to prevent brucellosis occurrence and prevalence on Omsk region territory, local authorities approved on "Complex program for preventing and eliminating animal brucellosis and preventing population brucellosis morbidity in Omsk region in 20132017".

Our research goal was to examine potential occupational, epidemiologic, sanitaryhygienic, medical, and behavioral health risk factors in stock-breeders, veterinaries, and workers employed at meat-processing production who had contacts with brucellosisinfected animals and infected raw materials.

Data and methods. We examined working conditions at 202 working places at stockbreeding complexes which were occupied by workers with occupational chronic $(78.22 \% ; n$ $=158)$ and residual $(21.78 \% ; n=44)$ brucellosis. $26.23 \%(n=53)$ of patients were able to retrospectively detect the acute phase of the disease. $92.08 \%(n=186)$ workers caught brucellosis when they reached age of being able-bodied. Share of people having 3-1 disability group amounted to $91.1 \%(n=184)$. $38.12 \%(n=77)$ people infected with brucellosis were employed, $2.46 \%(n=5)$ of them had been retrained [10].

Working conditions, brucellosis infection probability, regularity and quality of prelimi- nary and periodical medical examination were studied as per data on sanitary-hygienic properties of working conditions (Appendix No. 2 to the Order by the RF Public Health Ministry No. 176 dated May 28, 2001), corresponding to the Guidelines P 2.2.2006-05 [7], outpatient clinic cards (standard form 025/y-04). We also allowed for the data taken from cards of epizootologic-epidemiologic examination of a zoogenous disease nidus (form № 391/y, approved by the Order of the USSR Public Health Ministry No. 789 dated June 11, 1987) and patients' questioning.

Brucellosis was diagnosed by infection diseases doctors and was confirmed by Burnet sample and Wright and Huddleston serological reactions. Correlation between the disease and an occupation was detected as per data from labor records books, records from outpatient clinic cards, sanitary-hygienic properties of working conditions, cards of epizootologic-epidemiologic examination of a zoogenous disease nidus, information from a veterinary service on seropositive cattle occurrence at a working place and absence of seropositive cattle on private farms.

Statistical analysis of the obtained results was performed with the use of Statistika 6.0, standard applied statistical software [8]. As we compared groups we checked statistical hypotheses with parametric Student's $t$ criterion for independent samplings, onefactor dispersion analysis (ANOVA) and $\chi^{2}$ criterion. Impact value parameter $\left(\eta^{2}\right)$ for an impact exerted by a factor feature on the result was estimated by factorial dispersion fracture $\left(D_{\text {fact }}\right)$ in the overall dispersion $\left(D_{\text {o- }}\right.$ verall), $\eta^{2}$ showed which share belonged to impacts exerted by an examined factor among all the other factors. Zero hypothesis was rejected at $p<0.05$.

Results and discussion. All the examined patients had occupational contact with brucellosis infectious agents. All the patients had working conditions which were assessed as hazardous (class 3.3) or even dangerous (class 4) as per biological hazardous substances content in working area air and probability of con- 
tacts with infectious and parasitic diseases agents.

$40.3 \%$ stock-breeders, $16.4 \%$ veterinaries, and $33.9 \%$ workers employed at meatprocessing production had to work in conditions with production microclimate parameters deviating from hygienic standards; their working conditions corresponded to class 3.1.

Temperature in working areas during cold season varied from +10 to $+15^{\circ} \mathrm{C}$ and on average was equal to $+12.0 \pm 1.2{ }^{\circ} \mathrm{C}$ with relative humidity being equal to $82.9 \pm 3.4 \%$, which corresponded to hazard class 3.1 .

Ammonia content in working area air corresponded to hazard class of working conditions (3.1 and 3.2) for all the veterinaries and $26.6 \%$ of stock breeders.

Organic dust concentrations in working area air exceeded MPC for $8.1 \%$ workers employed at meat-processing production (class 3.1).

$66.1 \%$ of workers employed at meatprocessing production had to work under artificial lighting conditions which corresponded to class 3.1.

Labor hardness of stock breeders and veterinaries was determined by the following: working in a standing position; long-term staying in a fixed position; manual handling and lifting cargos; body bendings; as for workers employed at meat production, their difficulties were multiple stereotype movements $(74.7 \%$ stock breeders and $24.7 \%$ veterinaries had working conditions of class $3.2 ; 62.9 \%$ workers employed at meat-processing production, class 3.2-3.3). As per labor intensity, 3.3\% stock breeders had working conditions which could be classified as hazardous, class 3.1; $32.9 \%$ veterinaries and $43.6 \%$ workers employed at meat-processing production, class 3.2 .

$64.3 \%$ stock breeders, $73.9 \%$ veterinaries, and $49.4 \%$ workers employed at meatprocessing production had disorders in work and rest regime (absence of fixed lunch breaks, overtime work, irregular days off and vacations), and shift work with shift rotation [2,
11]. Stock breeders had the longest working hours and working week together with the shortest vacation; veterinaries had the least number of days off. Besides, more than a half of our respondents had insufficient physical activity, they drank alcohol, smoked, ate unhealthy food; a significant number of them suffered from increased blood pressure, excessive body weight and obesity which can also be called self-destructive behavioral and metabolic health risk factors $[14,19]$ as they cause general and occupationally induced diseases.

A fracture of impacts exerted by cooling microclimate on joints functional defects amounted to $78.7 \%$; on vegetative-sensory polyneuropathy syndrome evolvement, $80.9 \%$. A fracture of impacts exerted by occupational stress (labor intensity) on encephalopathy syndrome amounted to $62.1 \%$ (Table 1).

Sanitary-hygienic and medical-preventive support for the examined stock breeders, veterinaries, and workers employed at meatprocessing production suffering from occupational brucellosis in Omsk region is given in the Table 2.

Allowing for the most mentioned parameters, we noted statistically significant discrepancies between workers employed at meatprocessing production and two other occupational groups. Workers employed at meatprocessing production had the most favorable conditions in terms of sanitary-hygienic provision (Table 2).

The biggest number of people who had medical examinations when being recruited was detected among workers employed at meat-processing production (53.2\%); the least number, among stock breeders $(4.5 \%)$.

Absence of preliminary medical examinations, and periodical ones being irregular and of low quality, as well as untimely appeal for medical aid prove that employers and employees have irresponsible medical behavior and the latter run behavioral risk factors as they do not attend occupational medical examinations [9]. 
Table 1

A fracture of impacts exerted by occupational factors on workers' modbidity and a degree of health disorders dependence on occupation (\%)

\begin{tabular}{|l|c|c|c|}
\hline \multicolumn{1}{|c|}{ Occupational factor } & Pathology & $\begin{array}{c}\text { Fracture of } \\
\text { impact, } \%\end{array}$ & $\begin{array}{c}\text { Degree of dependence on } \\
\text { occupation }\end{array}$ \\
\hline Unfavorable microclimate & Joint syndrome & $\begin{array}{c}78,7 \\
F=16,7 ; p<0,01^{*}\end{array}$ & Very high \\
\hline Unfavorable microclimate & $\begin{array}{c}\text { Vegetative-sensory poly- } \\
\text { neuropathy syndrome }\end{array}$ & $\begin{array}{c}80,9 \\
F=34,0 ; p<0,01 *\end{array}$ & Very high \\
\hline Labor intensity & Encephalopathy syndrome & $\begin{array}{c}62,1 \\
F=22,9 ; p<0,01 *\end{array}$ & Very high \\
\hline
\end{tabular}

Note: * means impact by an examined factor, which is statistically significant at $p<0.05$ (ANOVA); $F$ is Fischer criterion.

Table 2

Sanitary-hygienic and medical-preventive provision of workers

\begin{tabular}{|c|c|c|c|c|}
\hline \multirow[b]{2}{*}{ No. } & \multirow[b]{2}{*}{ Parameter } & \multicolumn{3}{|c|}{ Occupational group, \% } \\
\hline & & $\begin{array}{c}\text { Stock breeders } \\
\quad(n=67)\end{array}$ & $\begin{array}{l}\text { Veterinaries }(n= \\
73)\end{array}$ & $\begin{array}{l}\text { Workers em- } \\
\text { ployed at MPP } \\
\quad(n=62)\end{array}$ \\
\hline 1 & Territory being comfortable & $\begin{array}{c}11,2 \\
(p<0,0001) *\end{array}$ & $\begin{array}{c}25,4 \\
(p<0,0001) *\end{array}$ & 72,6 \\
\hline 2 & Centralized water supply & $\begin{array}{c}79,1 \\
(p=0,002) *\end{array}$ & $\begin{array}{c}73,9 \\
(p=0,0002) *\end{array}$ & 98,4 \\
\hline 3 & Hot water supply & $\begin{array}{c}67,2 \\
(p=0,0001) *\end{array}$ & $\begin{array}{c}87,7 \\
(p=0,2)\end{array}$ & 95,2 \\
\hline 4 & Disinfectants & $\begin{array}{c}11,9 \\
(p<0,0001) *\end{array}$ & $\begin{array}{c}16,5 \\
(p<0,0001) *\end{array}$ & 51,6 \\
\hline 5 & Shower cabins at working places & $\begin{array}{c}4,5 \\
(p<0,0001) *\end{array}$ & $\begin{array}{c}6,9 \\
(p<0,0001) *\end{array}$ & 93,5 \\
\hline 6 & Rooms for having meals & $\begin{array}{c}15,3 \\
(p<0,0001) *\end{array}$ & $\begin{array}{c}34,6 \\
(p<0,0001) *\end{array}$ & 96,7 \\
\hline 7 & Satisfactory amenity rooms & $\begin{array}{c}16,4 \\
(p<0,0001) *\end{array}$ & $\begin{array}{c}20,5 \\
(p<0,0001) *\end{array}$ & 82,3 \\
\hline 8 & $\begin{array}{l}\text { Tools for removal of abortus and } \\
\text { stillborn fetuses }\end{array}$ & $\begin{array}{c}16,4 \\
(p=0,01) *\end{array}$ & $\begin{array}{c}50,7 \\
(p=0,2)\end{array}$ & 38,7 \\
\hline 9 & $\begin{array}{l}\text { Centralized laundry of protective } \\
\text { clothing }\end{array}$ & $\begin{array}{c}0,0 \\
(p<0,0001) *\end{array}$ & $\begin{array}{c}16,4 \\
(p<0,0001) *\end{array}$ & 93,5 \\
\hline 10 & First aid kits & $\begin{array}{c}16,4 \\
(p<0,0001) *\end{array}$ & $\begin{array}{c}39,7 \\
(p=0,08)\end{array}$ & 56,5 \\
\hline 11 & Specialized burial grounds & $\begin{array}{c}32,8 \\
(p<0,0001) *\end{array}$ & $\begin{array}{c}76,7 \\
(p<0,0001) *\end{array}$ & 3,2 \\
\hline 12 & Cleaning agents & $\begin{array}{c}58,2 \\
(p=0,01) *\end{array}$ & $\begin{array}{c}57,5 \\
(p=0,01) *\end{array}$ & 80,7 \\
\hline 13 & Personal protection means & $\begin{array}{c}32,8 \\
(p=0,1) \\
\end{array}$ & $\begin{array}{c}19,2 \\
(p=0,001) *\end{array}$ & 48,4 \\
\hline 14 & Preliminary medical examinations & $\begin{array}{c}4,5 \\
(p<0,0001) *\end{array}$ & $\begin{array}{c}13,7 \\
(p<0,0001) *\end{array}$ & 53,2 \\
\hline 15 & Periodical medical examinations & $\begin{array}{c}58,2 \\
(p<0,0001) * \\
\end{array}$ & $\begin{array}{c}72,6 \\
(p=0,0001) *\end{array}$ & 98,4 \\
\hline
\end{tabular}

Note: * means discrepancies in comparison with workers employed at MPP are statistically significant $\left(\chi^{2}\right.$ criterion). 
As per data taken from cards of epizootologic-epidemiologic examination of a zoogenous disease nidus a number of infected people in occupational niduses varied from 2 to 5 people.

Observation of sanitary-epidemiologic regime at working places occupied by stock breeders, veterinaries, and workers employed at meat-processing production is given in the Table 3 .

Absence of disinfectants, cleaning agents, and first aid kits, absence of disinfection in a nidus and activities aimed at its elimination, absence of quarantine cause epidemiologic or disinfection risks [12].

The results given in the Tables 2-4 prove there are gross violations of sanitaryepidemiologic rules СП 3.1.7.2613-10 on brucellosis prevention [6].

The most probable factors for brucellosis infection catching are given in the Table 5.

$94.0 \%$ stock breeders, $89.0 \%$ veterinaries, and $83.9 \%$ workers employed at meatprocessing production had contacts with brucellosis-infected cattle. The rest of the examined workers had contacts with brucellosisinfected pigs and small cattle.

Table 3

Sanitary-epidemiologic regime observation

\begin{tabular}{|c|l|c|c|c|}
\hline \multirow{2}{*}{ No. } & \multicolumn{1}{|c|}{ Parameter } & \multicolumn{3}{|c|}{ Occupational group, \% } \\
\cline { 3 - 5 } & $\begin{array}{c}\text { Stock breed- } \\
\text { ers } \\
(n=67)\end{array}$ & $\begin{array}{c}\text { Veterinaries }(n= \\
73)\end{array}$ & $\begin{array}{c}\text { Workers em- } \\
\text { ployed at MPP } \\
(n=62)\end{array}$ \\
\hline 1 & $\begin{array}{l}\text { Laboratory examination of materials } \\
\text { taken from animals and from outer envi- } \\
\text { ronment }\end{array}$ & $80,6^{*}$ & $93,2^{*}$ & 50,0 \\
\hline 2 & Quarantine & 61,2 & 60,3 & - \\
\hline 3 & Vaccination of animals in a nidus & 29,9 & 46,6 & - \\
\hline 4 & $\begin{array}{l}\text { Slaughter of brucellosis-infected ani- } \\
\text { mals }\end{array}$ & $49,3^{*}$ & $71,2^{*}$ & 90,3 \\
\hline 5 & Disinfection in a nidus & - & $58,9^{*}$ & 83,9 \\
\hline 6 & Nidus elimination & 59,7 & 42,5 & - \\
\hline 7 & $\begin{array}{l}\text { Laboratory examination of people in- } \\
\text { fected with brucellosis }\end{array}$ & 94,0 & 97,3 & 53,2 \\
\hline 8 & $\begin{array}{l}\text { Number of patients who were vaccinat- } \\
\text { ed before the diseases }\end{array}$ & - & $2,7 *$ & 500,0 \\
\hline
\end{tabular}

Note: * means discrepancies in comparison with workers employed at MPP are statistically significant, $p<$ 0.05 .

Table 4

Violations of sanitary-epidemiologic regimes and rules that make for catching brucellosis

\begin{tabular}{|l|c|c|c|}
\hline \multirow{2}{*}{ Parameter } & \multicolumn{3}{|c|}{ Occupational group, \% } \\
\cline { 2 - 4 } & $\begin{array}{c}\text { Stock breeders } \\
(n=67)\end{array}$ & $\begin{array}{c}\text { Veterinaries }(n= \\
73)\end{array}$ & $\begin{array}{c}\text { Workers em- } \\
\text { ployed at MPP } \\
(n=62)\end{array}$ \\
\hline Animals keeping & 89,5 & 67,4 & - \\
\hline $\begin{array}{l}\text { Transportation, storage, and processing of stock- } \\
\text { breeding raw materials and other agricultural } \\
\text { products }\end{array}$ & - & - & 87,7 \\
\hline Agricultural and other works & 10,5 & - & - \\
\hline Slaughter, necropsy, skinning & - & $30,4^{*}$ & 12,3 \\
\hline Lambing & - & 2,2 & - \\
\hline
\end{tabular}

Note: * means discrepancies in comparison with workers employed at MPP are statistically significant $\left(\chi^{2}\right.$ criterion). 
The most probable factors which can cause catching brucellosis

\begin{tabular}{|l|c|c|c|}
\hline \multirow{2}{*}{\multicolumn{1}{|c|}{ Parameter }} & \multicolumn{3}{|c|}{ Occupational group, \% } \\
\cline { 2 - 4 } & $\begin{array}{c}\text { Stock breed- } \\
\text { ers } \\
(n=67)\end{array}$ & $\begin{array}{c}\text { Veterinaries }(n= \\
73)\end{array}$ & $\begin{array}{c}\text { Workers em- } \\
\text { ployed at MPP } \\
(n=62)\end{array}$ \\
\hline Stock-breeding raw materials and products & - & - & 88,7 \\
\hline Abortus fetuses, stillborn fetuses, and afterbirth & 36,8 & 58,9 & - \\
\hline Blood, urine, and other biological substrates & $\begin{array}{c}21,5(p= \\
0,18)\end{array}$ & $41,1 *$ & 11,3 \\
\hline Dung & 27,8 & - & - \\
\hline Milk and dairy products & 13,9 & - & - \\
\hline
\end{tabular}
terion).

Note: * means discrepancies in comparison with workers employed at MPP are statistically significant $\left(\chi^{2}\right.$ cri-

$16.4 \%$ stock breeders, $57.5 \%$ veterinary workers, and $22.6 \%$ workers employed at meatprocessing production were informed of a probability to be infected with brucellosis at their working place; the information came via three non-dialogue communicative models for spreading information on occupational health risks (limited parity, paternalistic, and formal one)

People infected with brucellosis were detected during prevention medical examination in $16.7 \%$ cases among stock breeders; in $13.7 \%$, among veterinaries; in $21.0 \%$, among workers employed at meat-processing production. As for the rest of the cases, brucellosis was diagnosed when a worker applied for medical aid.

Brucellosis was detected in $8.2 \%$ cases when veterinaries were examined as per epidemiologic reasons.

Time gaps between a start of the disease, brucellosis diagnosis, and correlation between the disease and an occupation, $M \pm s$

\begin{tabular}{|c|c|c|c|c|c|c|}
\hline \multirow{3}{*}{ Occupational groups } & \multicolumn{6}{|c|}{ Time gap } \\
\hline & \multicolumn{2}{|c|}{$\begin{array}{c}\text { Start of the disease and a } \\
\text { visit to a doctor }\end{array}$} & \multicolumn{2}{|c|}{$\begin{array}{l}\text { A visit to a doctor and } \\
\text { brucellosis diagnosis }\end{array}$} & \multicolumn{2}{|c|}{$\begin{array}{c}\text { Brucellosis diagnostics } \\
\text { and occupational disease } \\
\text { diagnostics }\end{array}$} \\
\hline & $\begin{array}{l}\text { Time gap, } \\
\text { years } \\
\text { (share of in- } \\
\text { fected, } \% \text { ) }\end{array}$ & $M \pm s$ & $\begin{array}{c}\text { Time gap, } \\
\text { years } \\
\text { (share of in- } \\
\text { fected, \%) }\end{array}$ & $M \pm s$ & $\begin{array}{l}\text { Time gap, } \\
\text { years } \\
\text { (share of in- } \\
\text { fected, } \% \text { ) }\end{array}$ & $M \pm s$ \\
\hline Stock breeders & $\begin{array}{c}7-15 \\
(59,7)\end{array}$ & $15,4 \pm 3,6$ & $\begin{array}{c}2-18 \\
(25,4)\end{array}$ & $12,9 \pm 1,9$ & $\begin{array}{c}2-31 \\
(64,2)\end{array}$ & $14,2 \pm 2,5$ \\
\hline Veterinaries & $\begin{array}{l}15-30 \\
(68,5)\end{array}$ & $11,5 \pm 2,3^{*}$ & $\begin{array}{c}2-38 \\
(56,2)\end{array}$ & $17,4 \pm 6,9 *$ & $\begin{array}{c}2-42 \\
(69,9)\end{array}$ & $11,7 \pm 2,1^{*}$ \\
\hline $\begin{array}{l}\text { Workers employed at } \\
\text { MPP }\end{array}$ & $\begin{array}{c}5-12 \\
(80,6)\end{array}$ & $7,4 \pm 1,7 * \wedge$ & $\begin{array}{c}2-34 \\
(96,8)\end{array}$ & $\begin{array}{l}15,9 \pm \\
1,7 * \wedge\end{array}$ & $\begin{array}{c}2-28 \\
(37,1)\end{array}$ & $\begin{array}{l}13,0 \pm \\
3,3 * \wedge\end{array}$ \\
\hline
\end{tabular}

Note: * means discrepancies in comparison with stock breeders; $\wedge$ means discrepancies in comparison with veterinaries are statistically significant (Student's $t$-criterion, $p<0.05$ ), material is given as average \pm standard deviation. 
Medical examinations were the most regular and qualitative in the group of workers employed at meat-processing production (as per $\chi^{2}$ data and Student's criterion).

Time gaps between the first visit to a doctor and up to the moment when brucellosis was diagnosed and a decision on occupational nature of the disease was taken are given in the Table 6.

Duration of contacts with infected animals or raw materials up to the moment when brucellosis was diagnosed amounted to 11-20 years for $38.6 \%$ patients, to more than 30 years for $21.4 \%$, less than 10 years for the rest.

Most examined workers $(69.3 \% ; n=140)$ applied for medical aid for the first time when 530 years had passed after the start of the disease and it proved their irresponsible medical behavior, high level of proneness to risk and selfdestruction (see Table 6). Time gap between a visit to a doctor and the moment when brucellosis was diagnosed amounted to 2-38 years for $58.4 \%(n=118)$. Even if Burnet sample was positive, brucellosis was diagnosed in $34.3 \%$ patients after 2-20 years, on average after $11.3 \pm$ 2.4 years. Time gap between the moment when brucellosis was diagnosed and detection of correlation between the disease and an occupation amounted to 2-42 years for $72.8 \%(n=147)$.

Late brucellosis diagnostics and late detection of correlation between the diseases and an occupation didn't allow to change a worker's employment rationally in due time and it caused re-infection, the disease growing graver, and even disability.

Conclusions. Late diagnostics of health disorders is the basic risk factor of brucellosis for workers employed at meat-processing production who have contacts with infected animals and raw materials. Reasons for late diagnostics are ignorance about possible brucellosis contagion at a working place; late appeal for medical health; rare preliminary medical examinations (in $4.5-13.7 \%$ of cases) and irregular periodical medical examinations $(62.7-$
$74.0 \%$ cases) organized by employers. Workers don't apply for medical aid and don't visit an occupational pathologist as they fear to lose their job and to be punished by their employers. Medical and preventive organizations don't provide the necessary quality of preliminary and periodical medical examinations. Late appeal for medical health results in clinical picture polymorphism and a patient has to be treated for a long time (years) visiting various doctors (surgeons, therapists, orthopedists, neurologists, vertebral pathologists, and rheumatologists).

Other substantial factors causing epidemiologic and disinfection risks (which could be partly called behavioral) detected in 67$100 \%$ of stock breeders and veterinaries were violations of anti-brucellosis regime made by workers themselves. There were no disinfectants and cleaning agents and/or first aid kits at working places. Absence of disinfection in niduses and no activities aimed at niduses elimination as well as absence of quarantine belong to the same group of factors.

There are additional parameters which make risks even worse; they are adverse occupational factors such as biological ones, vibrations and noise, cooling microclimate, ammonia, organic dust, uncomfortable lighting environment, labor hardness and intensity.

Besides, workers had to perform their job tasks with only short breaks or even without any fixed breaks; they often had to work overtime, and their vacations were irregular and too short. Therefore, organizational factors made their contribution into overall threats of workers' health disorders.

Absence and/or refusal to use personal protection means and personal hygiene means, working in a forced position together with significant physical strain and unfavorable working zone microclimate make a worker's organism more prone to the infection and make occupational brucellosis risk much higher. 


\section{References}

1. Borisov V.A. Sovremennoe sostoyanie problemy brutselleza [Contemporary state of brucellosis problem]. Zhurnal infektsionnoi patologii, 2000, vol. 7, no. 1-2, pp. 57-59 (in Russian).

2. Bukhtiyarov I.V., Rubtsov M.Yu. Cmennyi trud kak faktor kantserogennogo riska [Shift work as carcinogenic risk factor]. Mezhdunarodnyi nauchno-issledovatel'skii zhurnal, 2016, vol. 53, no. 11-3, pp. 134-137 (in Russian).

3. O merakh po realizatsii polnomochii Edinoi gosudarstvennoi Federal'noi tsentralizovannoi sistemy gosudarstvennogo sanitarno-epidemiologicheskogo nadzora $\mathrm{v}$ oblasti obespecheniya biologicheskoi $\mathrm{i}$ khimicheskoi bezopasnosti: postanovlenie glavnogo gosudarstvennogo sanitarnogo vracha Rossiiskoi Federatsii № 50 ot 04.08 .09 g. [On activities aimed at implementation of authority by Integrated State Federal Centralized System of state sanitary-epidemiologic surveillance in the sphere of providing biological and chemical safety: resolution by the RF Chief State Sanitary Inspector No. 50 dated August 04, 09]. Available at: https: //www.garant.ru/products/ipo/prime/doc/4089061/ (09.12.2016) (in Russian).

4. Orakbai L.Zh., Cherepanova L.Yu., Denisova T.G. Sovremennye aspekty epidemicheskogo protsessa brutselleza [Contemporary aspects of brucellosis epidemic process]. Sovremennye aspekty nauki i obrazovaniya, 2015, no. 6. Available at: https: //www.science-education.ru/ru/article/view? id = 22737 (25.05.2017) (in Russian).

5. Dobrokhotskii O.N., Mushchak I.P., Kirpichenkov A.B., Dyatlov I.A., Zar'kov K.A. Proektirovanie laboratorii - klyuchevoe zveno upravleniya bioriskami pri rabote s patogennymi biologicheskimi agentami [Designing of laboratories is crucial for the management of biorisks in the work with pathogenic biological agents]. Gigiena i sanitariya, 2014, vol. 93, no. 6, pp. 59-61 (in Russian).

6. Profilaktika brutselleza: Sanitarnye normy i pravila 3.1.7.2613-10 [Prevention of brucellosis: sanitary standards and rules 3.1.7.2613-10]. utv. postanovleniem Glavnogo gosudarstvennogo sanitarnogo vracha RF ot 26.04.2010 № 39 [approved by resolution by the RF Chief State Sanitary Inspector dated April 26, 2010 No. 39]. Available at: http: //89.rospotrebnadzor.ru/documents/ros/postanov/30197/ (09.12.2016) (in Russian).

7. Rukovodstvo po gigienicheskoi otsenke faktorov rabochei sredy i trudovogo protsessa. Kriterii i klassifikatsiya uslovii truda. R 2.2.2006-05. [Guide on Hygienic Assessment of Factors of Working Environment and Work Load. Criteria and Classification of Working Conditions]. Available at: http: //www.kadrovik.ru/docs/rukovodstvo.2.2.2006-05.htm (12.12.2016) (in Russian).

8. Rebrova O.Yu. Statisticheskii analiz meditsinskikh dannykh. Primenenie paketa prikladnykh programm STATISTICA [Statistic analysis of medical data. Use of STATISTICA applied software]. Moscow, Media Sfera Publ., 2002, 312 p. (in Russian).

9. Ryazanova E.A., Lebedeva-Nesevrya N.A. Riskovoe povedenie rabotnikov v sfere zdorov'ya kak faktor poter' trudovogo potentsiala promyshlennogo predpriyatiya [Workers' health risk behavior as a factor of labour potential losses of industrial enterprises]. Aktual'nye problemy razvitiya chelovecheskogo potentsiala $v$ sovremennom obshchestve. Institutsional'nye izmeneniya $v$ Rossii $i$ mire: Materialy Mezhdunarodnoi nauchno-prakticheskoi internet-konferentsii [Vital issues of human potential development in contemporary society. Institutional changes in Russia and worldwide: materials of the International theoretical and practical Internet-conference]. Perm', Permskii gosudarstvennyi natsional'nyi issledovatel'skii universitet Publ., 2015, pp. 13-16 (in Russian).

10. Ereniev S.I., Demchenko V.G., Plotnikova O.V., Safonov A.D., Rudakov N.V. Gordienko, L.N., Ponomareva O.G., Tarkhov A.E. Sanitarno-gigienicheskie i kliniko-immunologicheskie aspekty professional'nogo brutselleza v sovremennykh usloviyakh [Sanitary-hygienic and clinical-immunologic aspects of occupational brucellosis in contemporary conditions]. In: V.G. Demchenko, A.D. Safonova, N.V. Rudakova, S.I. Erenieva eds. St-Peterburg: TESSA Publ., 2014, 220 p. (in Russian).

11. Spirin V.F., Novikova T.A. Gigienicheskie aspekty upravleniya professional'nymi riskami u rabotnikov sel'skogo khozyaistva [Occupational risk control in rural workers: Hygienic aspects]. Zdravookhranenie Rossiiskoi Federatsii, 2008, no. 1, pp. 19-20 (in Russian).

12. Shestopalov N.V. Sovershenstvovanie dezinfektsionnoi deyatel'nosti i profilaktika infektsionnykh boleznei cheloveka [Совершенствование дезинфекционной деятельности и профилактика инфекционных болезней человека]. Meditsinskii alfavit, 2013, vol. 1, no. 5, pp. 5-7 (in Russian).

13. Rudakov N.V., Yastrebov V.K., Yakimenko V.V., Rudakova S.A., Samoilenko I.E., Poleshchuk 
E.M. Epidemiologicheskaya otsenka territorii riska zarazheniya naseleniya prirodno-ochagovymi i zoonoznymi infektsiyami v prigranichnykh regionakh Sibiri [Epidemiological evaluation of contagion risk of the population natural focal and zoonotic infections in the frontier regions of Siberia]. Dal'nevostochnyi zhurnal infektsionnoi patologii, 2015, no. 27, pp. 17-19 (in Russian).

14. Behavioral Risk Factor Surveillance System Questionnaire. Available at: http: //www.cdc.gov/brfss/questionnaires/pdf-ques/2014_brfss.pdf (09.12.2016).

15. Boschiroli M., Foulongne V., O'Callaghan D. Brucellosis: a worldwide zoonosis. Curr. Opin. Microbiol, 2001, vol. 4, no. 1, pp. 58-64.

16. Bricker B.J. PCR as a diagnostic tool for brucellosis. Vet. Microbiol, 2002, vol. 90, no. 1-4, pp. 435-446.

17. Almuneef M.A., Memish Z.A., Balkhy H.H., Alotaibi B. [et al]. Importance of screening household members of acute brucellosis cases in endemic areas. Epidemiol. Infect, 2004, vol. 132, pp. 533540 .

18. Mantur B.G., Amarnath S.K., Shinde R.S. Review of clinical and laboratory features of human Brucellosis. Indian J. of Medical Microbiology, 2007, vol. 25, no. 3, pp. 188-202.

19. Chowdhury P.P., Mawokomatanda T., Xu F. [et al.]. Surveillance for Certain Health Behaviors, Chronic Diseases and Conditions, Access to health Care, and Use to Preventive Health Services Among States and Selected Local Areas - Behavioral Risk Factor Surveillance System, United States, 2012. MMWR Surveil. Sum, 2016, vol. 65, no. SS-4, pp. 1-142.

20. Zheludkov M.M., Tsirelson I.E., Kulakov Y.K. Human brucellosis in Russia. Mater. Intern. Confer. Brucellosis, London, 2008, pp 125.

Ereniev S.I., Plotnikova O.V., Demchenko V.G., Rudakov N.V. Biological, epidemiological, sanitary-hygienic, medical and behavioral occupational health risk factors for stock-breeders, veterinaries and workers employed at meat-processing enterprises, contacting brucellar animals and infected meat. Health Risk Analysis, 2017, no. 2, pp. 94-103. DOI: 10.21668/health.risk/2017.2.11.eng

Received: 12.01 .2017

Accepted: 20.03 .2017

Published: 30.06 .2017 